\title{
The persistence of, and challenges to, societal effects in the context of global competition
}

Phil Almond

\section{Introduction}

The notion of the 'societal effect', as posited by the Laboratoire d'Economie et de Sociologie du Travail (LEST) school (Maurice et al., 1986), has long represented a bulwark against universalist thinking within research into labour markets, the wider structuration of the wage-employment relationship and organisation studies.

The specific methodological commitments of the LEST school itself (see the appendices to Maurice et al., 1986) are perhaps more honoured in the breach than in the observance. However, the underpinning idea of the importance of integrating 'the comparison and analysis of the genesis and dynamics of institutional forms, social rules, policies and cultures' (Michon, 1992: 223) into an analysis of economic systems has inspired a broad comparative literature on the organisation of capitalism (Hall and Soskice, 2001; Lane, 1989; Whitley, 1992, 1999). This broader literature is sometimes referred to as 'societal institutionalism’ (Djelic and Quack, 2003). When applied to labour market organisation, this stresses the idea that labour supply and demand are the result not of the application of abstract economic norms, but of mutually interlocking spheres of social structuring of the opportunities and constraints facing work organisation and workers (see Rubery, 1992).

Essentially, societal institutionalism argues that capitalism is embedded at a national-societal level in mutually reinforcing and interlocking 'spheres' of political economy, in ways which create national 'logics' of employment relations, labour market construction and production organisation which combine to create a certain degree of internal coherence. As we will reflect on below, in 
contemporary societal institutionalist work there are different degrees of insistence on, or questioning of, the national closure of such logics, and implicitly on the long-controversial concept of 'coherence', and how far this implies functionality (Maurice and Sorge, 2000; Rubery, 1992). However, this embeddedness, or process of institutionalised social construction, is a necessary feature of the complex socio-economic relations involved in the reproduction of capitalism within specific political-geographical spaces, rather than being only a feature of those societies which depart more obviously from liberal norms of the employment relationship. Thus 'the notion of juxtaposing a labour market structured by institutions and a deregulated labour market structured by market forces is invalid. If explicit labour market regulations are dismantled then the labour market will be exposed to the influences of firm-specific employment policies on the one hand and the institutions of social reproduction on the other, with no regulatory systems or norms to restrict the extent of inequality or segmentation' (Rubery, 1992: 258).

Methodologically, societal institutionalism was originally developed in conscious opposition to approaches, often based in forms of contingency theory, which try to draw relations between variables in all national environments, 'posing the existence of a rationality above and beyond national specifics and cultural particularities' (Maurice, 1979: 43). Maurice was referring to research using contingencies drawn from organisational theory (Lammers and Hickson, 1979), such as markets, technology and size. However, it is also the case that a fairly large volume of cross-sectional international research, often based on statistical comparisons of a large number of countries, uses indicators of more macro-level economic, social and political characteristics.

The debate between formal contingency approaches and internationally comparative methods no longer has the prominence it once did (see the various contributions to Lammers and Hickson, 1979). In practice, however, a very considerable volume of international research follows the precepts of comparing standard variables, divorced from their socio-political-cultural contexts, in making statements about differences in outcomes at national level. These 'thin' forms of comparison are favoured by the political economy of research, in particular through the frequent need for research to cover large numbers of countries due to funder requirements, and the incentives to make positivistic claims about the relations between variables across as large a number of countries as possible.

Societal institutionalism rejects such cross-sectional analysis, at least as the sole form of comparative research. Instead it argues that analysis of labour market construction, or of organisational decision-making, must be predicated on an understanding of how the dependent variable(s) of interest are socially 
constructed through the interplay of a large range of forces, or societal 'spheres', which interact together in mutually co-constitutive ways. For the original LEST research of Maurice and colleagues, a comparison of internal labour markets in industrial firms in France and Germany required an analysis of the mutual co-constitution of the educational and vocational training system, the nature of business organisation, and the structure of employer-worker struggle in the industrial relations sphere. For societal analysis, it is essential to analyse how these 'spheres' are constructed in different societies, and how they relate to each other; the best research in this tradition goes beyond positing institutional logics and attempts to understand the socialised rationality of actors (see the methodological appendix to Maurice et al., 1986).

Rubery's work provides an illustration of how such a methodology might proceed, which is worth quoting at length:

According to the LEST school, it is in fact crucial to understand the articulation of social and economic organisation within a given society and not seek to find universal patterns between societies through cross-sectional analysis. Apparently similar forms of economic or social organisation may in fact serve very different functions within different societies. To take part-time employment as an example, before it can be determined what role part-time work plays in absorbing surplus labour in recessions..., it is necessary to undertake a detailed analysis of, amongst other factors, the share of the informal economy, the overall participation rates, the measured level of unemployment, the family division of labour and hours of work for full-timers, and the role of part-time work in the productive system. In short the relative importance of the role of part-time work in disguising unemployment cannot be simply read off from a comparison of the shares of part-time work between societies. (Rubery, 1992: 247)

Societal institutionalist literature outside the original LEST school, and other comparative frameworks strongly influenced by the LEST principles of comparison, is often interested in different 'spheres' and 'interlockages'. Indeed, societal institutionalist research needs to be wary of concretising the explanatory factors that it investigates too strictly, as 'deep' comparativism can only achieve its objectives to the extent that the researcher is confident of having understood the relevant interdependencies and interconnections between all the different spheres of social space which shape his/her particular area of interest. These are likely to change if the research focus changes, and may also vary themselves across societies. Thus while the spheres elucidated by the LEST school and other societal institutionalists are helpful as a guide, for a given concrete piece of research the relevant 'spheres' and their 'interlockages' can only really be discovered inductively, and may emerge in a relatively ad hoc way in the research process. For example, in our own comparative research on the involvement of 
social actors in the attraction and retention of foreign direct investment (FDI), the structuring of territorial politics, and the channelling of populist as opposed to mainstream politics, emerged as key co-constitutive variables (Almond et al., 2017). Thus, we would argue that the precise labelling of spheres is less important than retaining the core idea of a system of interlocking societal spheres structuring economic organisation (or for labour market analysis more specifically, labour supply and demand).

\section{Challenges for societal institutionalist analysis}

Sympathetic critics of societal institutionalism have tended to focus on the somewhat functionalist approach of the LEST school - exacerbated, we would argue, in some subsequent work influenced by it, particularly the varieties of capitalism approach (see Almond and Gonzalez, 2006) - and consequent difficulties in developing 'a dynamic analysis of change in societal organisation, as change usually arises out of conflict and tension and not out of harmony and complementarity' (Rubery, 1992: 248). Somewhat relatedly, sympathisers and critics alike have questioned the merits of defending specifically national-societal embeddedness, in the context of international integration over the last 30 years.

Part of the problem in analysing change arises if the notions of 'coherence' and societal 'logics' are taken to mean that it is necessary to boil societal effects down into underpinning guiding forces of national capitalisms. This is a frequent but in our view non-necessary component of societal institutionalist research - it should be possible to trace the mutual interactions of conflicts and power struggles in different spheres of society, and identify the logics these interactions embody, without positing that these interlockages provide path dependencies that are necessarily 'coherent' in the sense of being functional (see Rubery, 1994 on the UK productive system). Indeed, the recent trend towards a more actorcentred institutionalism analysing the role of actors in changing institutions (e.g. Streeck and Thelen, 2005) is strongly affected by societal institutionalism, at the same time as questioning the national stability of societal systems as regulatory forces under neoliberal globalisation.

Equally, it is clearly the case that any sort of 'coherence' of national-societal systems is predicated on some sort of coherence with the demands of international political economy and globalising capitalism. To be practically adequate, comparative analysis needs both to take systematic account of the selective 'efficiency' of societies as informed by processes of international integration (Rubery, 1992; Wilkinson, 1983), and to recognise that these processes imply that institutional embeddedness is not exclusively at the national level. This 
means taking into more systematic account sectoral and sub-national variations (Rubery, 1992: 248), as well as supranational or transnational structuration.

The remainder of this chapter revisits some of these challenges, in the context of the transnationalisation of productive capital, and the dynamics of regime competition that have ensued at national and more local levels. We argue that it is important to retain an emphasis on the mutual interdependencies shaping the social construction of labour markets, while giving greater emphasis to the ways that, within 'variegated' neoliberal capitalism (Peck and Theodore, 2007), the dynamics of competitiveness both depend on, but also challenge, relatively coherent 'societal' fixes as to the nature of socio-productive systems.

\section{International competition and societal effects}

At one level, specific factors causing increased international competition for production can readily be identified: the more systematic incorporation of large parts of the Global South into global circuits of capital; trade liberalisation at continental and transnational levels; the financialisation of the firm; and the variety of ways in which technology and product market liberalisation have enabled markets to be serviced remotely and enabled more accurate surveillance of the international operations of multinational firms.

Notwithstanding current nationalist-populist challenges, these factors are related to a broad shift in the emphases of national governments, from the protection and development of national productive capitalisms to securing positions in international contests for mobile investment (Jessop, 2004). Countries - but also cities, subnational regions and, to an extent, supranational trade blocs engage in competition to attract private-sector investment. More broadly, policy decisions are inflected by efforts to develop or maintain international or global 'competitiveness' (Pedersen, 2010), influenced not only by flows of capital but also by the active agency of transnational regulators. In other words, the contemporary international organisation of production and the nature of state regulation are intricately intertwined; the state, at regional, national and supranational levels, has been and remains a constitutive actor in enabling and reproducing patterns of international competition, through active processes of re-regulation, both of product markets and of factors of production, including labour (Cerny, 1997; Jessop, 2013).

Where does this leave societal-level analysis? One stock answer to the challenges of globalisation for societal institutionalists has been to posit some form of comparative institutional advantage, such that the nature of coordination used in a national economy will present it with certain advantages in specific types of 
production (Sorge, 1991). Thus Germany and the other densely institutionalised economies labelled by varieties of capitalism analysts as 'coordinated market economies' have advantages in sectors where progress is built upon incremental improvements in engineering, requiring collaborative relationships between employers and highly competent, adaptable employees, aided by patient capital. But despite the continued popularity of the varieties of capitalism argument as a device for labelling national economies, Hall and Soskice's (2001) vision of globalisation leading to a relatively benign process of nations building upon their path-dependent institutionalised strengths seems over-optimistic, given the extent to which liberalising pressures have been felt even in the core 'coordinated market economies' such as Germany (Holst, 2013), and the broader difficulties faced in persuading individual firms to tolerate 'constraints', even if their effects are acknowledged to be beneficial at an aggregate, national level (Marsden, 2015). In other words, the globalisation of capital makes free-riding by firms very much easier in weakening any notion of solidarity within national capitalisms. The locational flexibility of important fractions of productive capital is a key factor here.

\section{Multinationals, regime shopping, resource shopping and societal effects}

It is important to take explicit account of the fact that multinational companies (MNCs) can, to greater or lesser extents, choose where to locate. 'Regimeshopping' (Streeck, 1991) has many different aspects, including notably fiscal and labour regulation. Following societal institutionalism, we would argue that favourable forms of societal-institutional embeddedness (e.g. skills institutions with favourable outputs and so on) as well as the local-national availability of particular forms of extra-firm coordination (e.g. access to innovation networks, relations with local firms and so on) are one set of forces structuring MNC choices about location.

If different societal-institutional complexes create possibilities for competitive advantage in specific fields of activity, then a certain degree of self-selection is likely to take place as to which types of foreign direct investor have significant presence in which types of national business system. If this argument holds, then how MNCs behave in terms of their interactions with host-domestic institutions, and the degree of compatibility between the supply of, and demand for, specific forms of institutional resources, are likely to operate substantially differently between different types of national economy. Thus, in this case, regime shopping by MNCs may reinforce national and local institutional complementarities 
and contribute to divergence between business systems in different locations, as represented in Hall and Soskice's (2001) discussion of globalisation as a relatively benign force, at least for coordinated and liberal market economies.

Alternatively, if international market and political pressures on societies to follow uniform means of competing for productive investment are strong enough to disturb fundamentally the socio-economic foundations of host institutions, then patterns of firm coordination within MNCs may move back more within the hierarchy of the global firm itself, and its dependent supplier networks. Given evidence of the important role of the state and of sociohistorically contingent institutions in promoting innovation (Crouch, 2005), such a development would be unlikely to have positive consequences even if our only interest were in the promotion of exportable innovation. Such a vision would also have negative implications for visions of MNCs as leading local economic development in ways that produce positive-sum games with localised productive systems, as positive spillover effects from MNCs to host economies would be more limited.

In seeking the reality between these alternate binary positions, it is important also to disaggregate the MNC itself (Dörrenbächer and Geppert, 2011). To a societal institutionalist, societal systems provide the resources allowing firms to compete, and do so in different ways in different types of business systems. For an MNC which has choices about location, each host business system is to some extent a 'supplier of embeddedness', operating in competition with systems elsewhere. However, to managers of a particular subsidiary unit, the specific host business system is the only one available. This may mean that managerial interest in attempts to create productive links in host economies differs between different levels of the international firm - local managers may have powerful incentives to find ways of collaborating with other local actors to achieve productivity, financial or other targets, even if corporate actors have little interest. Where regime competition is particularly intense, as, for example, in the automobile industry, the places that are successful in attracting new investment often benefit from tight networks between the local/national state, development agencies and labour market institutional actors (Hudson, 2003). In such cases, regime competition and insecurity of future investment may lead to greater, rather than lesser, degrees of associational/network 'embeddedness' with these non-firm actors, at the same time as co-opting local institutions to the vagaries of international competition.

These processes of ongoing competition for productive investment have been extensively researched by a literature on global production networks (GPNs) (see Coe and Yeung, 2015), which gives analytical priority to how lead firms coordinate international production through relations with a wide range of 
actors. These include dependent firms, the state at various geographical levels, education, training and research infrastructures, and a wide range of associational actors, including employers' associations and trade unions. It therefore attempts to locate an analysis of the roles of such actors within geographically and organisationally 'fragmented' (Herrigel and Zeitlin, 2010), yet still actively coordinated, international networks of the production and exploitation of value.

Importantly, for GPN scholars, the strategies regional actors must adopt to develop favourable positions in global production networks go beyond the more established notions of 'comparative institutional advantage' often found in the comparative capitalisms literature. In other words, while comparative institutionalists often posit relatively 'static' forms of comparative advantage, work on global production networks sees the relationship between regions and firms as a more dynamic relationship of 'coupling' (Coe et al., 2004). This core concept implies that there is, or needs to be, a continual process of adaptation of 'host' human and other resources to the constantly evolving needs of firms within global production networks. These processes of adaptation are not limited to occasional institutional reforms; rather, they refer to continual, mutually adaptive, relations between international firms and geographically embedded state and other governance actors.

In arguing for an explicit consideration of how regional actors activate networks in order to respond to the demands of international competition, the GPN literature builds upon, and extends, earlier arguments within regional studies and economic geography that the global fragmentation of production was likely to cause the local network embeddedness of the subsidiary operations of MNCs to increase (e.g. Morgan, 1997). Routine branch plants, serving national markets and operating to well-established corporate production methods, could often function with limited interactions with local business system actors. However, where lead firms develop the capacity to make fine-grained decisions about the geographical and organisational location of their activities, subsidiary units increasingly compete to exercise functions, or 'mandates', on an international basis (Birkinshaw, 2013), which may be global or at the level of the supranational 'region'. Units which are unsuccessful in these contests are increasingly marginalised, and threatened in cases where access to markets no longer requires the existence of local/national 'branches'.

Clearly, the fact that much productive investment is mobile makes it much more difficult for regional governments, businesses, employees and trade unions to reach long-term relationships with inward investors. However, this marked shift in the balance of power does not mean that the role of host institutions has been reduced to a simple avoidance of 'constraints'. Rather, host institutions have been repurposed to at least some extent, as the attraction and retention of the 
investment and jobs associated with the high value-added components of global production networks require that regional and national actors seek, through the agency of their business system actors, to provide embedded resources.

\section{Societal institutionalism and multinational companies}

Although research in the coordination of MNC subsidiaries often argues that international firms need to develop local (network) embeddedness (e.g. Andersson et al., 2002) this works shows, for the most part, very limited interest in the wider social contexts which underpin the extent and type of network relations which an MNC might pursue. It therefore largely ignores the structures of incentives and constraints which shape the ability and willingness of MNCs and of local network actors to participate in the relations of trust and mutual obligation which it focuses on. If it is true that 'a unit's most important resource is the web of specific relationships in which the subsidiary is embedded' (Andersson and Forsgren, 1996: 487), then it is vital, particularly for comparative and policy-oriented research, to take much more serious account of an array of research which indicates that national business and innovation systems differ from each other in non-trivial ways, even between countries of comparable wealth and development (Lundvall, 2010), and that sophisticated MNCs are capable of taking these differences into account when deciding where to locate different types of activities (Cantwell and Iammarino, 2000). It is here that societal institutionalist research can make a key contribution.

The societal institutionalist view has frequently been deployed in the human resource management and organisational studies literatures in order to investigate the multiple embeddedness of MNCs in different national structures for the coordination of capitalism (Bélanger et al., 2013; Dörrenbächer and Geppert, 2011). There is a substantial literature on how MNC capabilities and behaviours are affected by elements of the socio-economic structure of their countries of origin - whether MNCs 'attempt to take with them and apply their own, nationally idiosyncratic, repertoire of HRM [human resource management] practices to their subsidiaries in foreign countries' (Gooderham et al., 2006: 1507). Equally, there is a wide range of research examining the influences of societal effects on the management of MNC host units (Belizón et al. 2013; Parry et al., 2008; Saka-Helmout and Geppert, 2011;).

Host societal embeddedness is sometimes viewed as causing constraints; societal effects, whether in the form of concrete institutions or more diffuse artefacts of culture or ideology, may impede MNCs in attempts to achieve commonalities of organisational policies across their international operations 
(e.g. Myloni et al., 2004). However, while these may be constraints from the perspective of corporate HQ managers, they may present opportunities for subsidiary-level managers, who may derive power resources from their ability to interpret local host environments and the limitations and possibilities these raise for corporate action. Possessing this institutional understanding, and being able to apply it in the context of the MNC, is likely to complement the potential relational advantages of host managers being embedded in the host environment. As argued above, however, and particularly given regime competition, host-country institutions do not only provide MNCs with constraints (indeed, if they did, there would be much less FDI), but rather more focus should be placed on both (relatively) static comparative institutional advantage and more dynamic patterns of relational or network embeddedness in MNCs' interactions with host societies.

Thus while societal institutionalist literature on MNCs has predominantly concentrated on firms' internal management structures and processes, it also argues that firms' embeddedness in national institutions is likely to have implications for how they coordinate relations with external actors (Morgan, 2001). The ability of subsidiary-level actors to network usefully in their host environments cannot be assumed. Neither is it simply a question of good management. Rather, the capacity to establish embedded patterns of relations is shaped by the nature of local and national institutions (Kristensen and Zeitlin, 2005): what host economy actors may contribute to the capacity of the MNC unit to compete internationally, and how national and local patterns of relations of trust and authority operate, both between different firms and, more broadly, between firms, labour, the state and civil society organisations.

Logically, firms are more likely voluntarily to engage in external relations, and therefore have a more active effect on the performativity of local institutions, the more there are actors within the host context with whom there is demonstrable value-added in coordinating. These may include, for example, supplier and other related firms who have the capacity to engage with MNCs in relational contracting, or institutional actors, such as labour market system actors capable of providing, or co-producing, local human resource advantages. Such relations, perhaps particularly those with institutional actors, are more likely to operate successfully where host institutions empower actors to engage in localised innovation (Maskell and Malmberg, 1999). This includes institutional innovation, or what has sometimes been termed 'experimentation', where social actors develop the capacities and capabilities necessary to allow interactions on a flexible basis without threatening the stability of the overall institutional architecture (Morgan and Kristensen, 2006).

The capacity of firm and non-firm actors to engage in long-term coordination is, of course, a core concern of societal institutionalism. A simplistic 
interpretation of work in this tradition tends to argue that non-market, longterm, trust-based relations are of more importance in 'coordinated market economies' such as Germany and Japan, as opposed to the market and hierarchycentred creation and exploitation of resources in more liberal economies (Hall and Soskice, 2001). However, there is obvious evidence of relational coordination in liberal economies; one need only think of well-known clusters of activity such as Silicon Valley, or life sciences around Cambridge, UK, to see examples of firms in such economies behaving in decidedly 'coordinated', or at least networked, ways (Crouch, 2005). Such cases may be exceptions to the national rule, explained by local or sectoral specificities, or by the importance of state institutions in embedding activities in strategically important sectors. However, they nonetheless point to the need for a granular analysis of how national social structure shapes patterns of firm coordination.

Equally, and importantly in so far as a discussion on societal institutionalism is concerned, the institutionalised patterns of transactions said to favour high-trust patterns of 'relational embeddedness' in countries such as Germany and Japan were developed historically with domestic firms (and the core industrial labour force) as key stakeholders, not foreign MNCs. There is insufficient systemic empirical evidence as to the extent to which foreign MNCs voluntarily engage in such forms of embeddedness in the most 'coordinated market' economies. Theoretically, though, it may well be possible for inward investors to obtain at least some of the institutionalised advantages such countries are often argued to present - such as high-skilled, adaptable workforces - through free-riding. There are certainly some signs of this in economies with intermediate levels of coordination (Almond et al., 2014).

Finally, any comparative analysis in this area needs to get a much clearer picture of what happens when host institutions are seen as inadequate. If slotting into existing host-economy patterns of coordination is inadequate for the needs of the MNC, then at least two possibilities would seem to be available. On the one hand, foreign MNC units might develop fewer voluntary active links with network actors in the domestic economy, and rely to a greater extent on their own internal global networks and hierarchies, alongside their market power in standard contractual relations. Alternatively, they may choose to engage in various forms of institution-building, taking the business of creating frameworks for the development of external coordination with local firms, civil society actors and governments into their own hands.

In summary, we would expect patterns of relations to differ across the various sorts of host political economies. But the picture is almost certainly more complicated than simply positing that the volume of external network linkages is greater in one 'variety of capitalism' than another. Tracing the nature of such potential 
cross-national differences, and their interactions with standard contingencies such as sector, technology and so on, is likely to require an analysis built on the thick description of relational networks, and what they mean to the actors concerned.

On the whole, where the international management literature explores relations between $\mathrm{MNC}$ units and host economies, it tends implicitly to concentrate on involvement in innovation networks and relations with local firms that are assumed to have the potential to result in positive-sum games. Yet it is frequently the case that subsidiary units engage with local/national institutions or networks for more defensive or tactical reasons. For example, firms which would prefer not to have relations with institutions representing collective labour may be required to do so in some host environments. Equally, access into some markets requires joint ventures with domestic firms, which the MNC might not have chosen freely. Further, host states or localities frequently tie subsidies and other forms of state support to the establishment of links with local firms, universities or other actors. While the latter arrangements may be voluntary, they nonetheless represent the host state shaping the 'market' for 'embeddedness'.

Some of these arrangements may well eventually create outcomes which the MNC unit is able to turn to its advantage, and indeed doing so is a key skill in subsidiary management. This does not alter the fact that their original impetus, from an MNC perspective, is either tactical or defensive. Unless it results in some form of perceived local advantage, 'involuntary' relations are particularly liable to being opposed by MNCs; this is therefore one of the areas in which MNCs are particularly likely to challenge elements of established institutionalised societal systems.

\section{Global, national and local effects}

As observed above, early societal institutionalism, itself embedded in the relatively solid societal arrangements of 1970s/1980s France and (West) Germany, was over-confident in stressing that the national society (and national sovereign state) was the container of societal effects. It is clear, though, that contemporary societal institutionalism cannot depend solely on a vision of relatively contained national systems, given that their integrity has been increasingly challenged by transnational influences, usually of a neoliberalising nature. This can very clearly be seen in the productive sphere, not just through the international firm per se, but more broadly by the reconfiguration of productive capitalism into global production networks. Equally, it is very clear that financial systems are strongly interdependent, and also that regulatory national sovereignty is conditional, as has been amply demonstrated in the course of the crisis in Southern Europe. 
At the same time, when investigating how global productive networks interact with host societies, it is clear that many demonstrable 'societal' effects which influence the nature of $\mathrm{MNCs}$ ' relations with host economies and societies are relatively local in scope. It is also not a coincidence that globalisation has increasingly gone hand in hand with questioning of the national sovereign state from 'below'. In some of these cases, it is probably relatively uncontroversial to say that 'subnational' societal effects are strong enough that specific places merit, for some comparative purposes, somewhat separate treatment. Quebec, in some respects, may not appear to have a very 'Canadian' variant of capitalist governance, for example (Almond et al., 2014).

Additionally, it has sometimes been argued that the shifts in the functions of economic governance actors associated with a focus on international competitiveness have been, or should be, accompanied by shifts in the levels of governance. The nation state, in other words, becomes increasingly 'leaky' as a 'container of governance' (Brenner et al., 2003). Its coordinating capacities are fragmented, with some capacity transferred upwards (e.g. supranational or transnational institutions providing competition rules) and some downwards (with subnational regions or localities charged with developing flexible infrastructure, and tailoring to local economic and social needs). Influential ideas on industrial policy, not least of which is the current EU institutionalisation of 'smart specialisation' through Regional Innovation Strategies (RIS3) (see European Commission, 2014), provide examples of this; regional governments are charged with identifying their potential competitive strengths, and how these might be operationalised, in association with producer and user stakeholders.

Clearly, if nothing else, the political situation of the UK at the time of writing should alert us to the danger of teleology with such claims. The balance between geographical levels of governance, and thus the resources available to state and other governance actors at subnational levels, remains heavily contingent on national systems of political and economic governance, which themselves differ for deeply societally embedded reasons. Nonetheless, societal institutionalist research must be able to accommodate various effective geographical levels of the 'societal' construction of capitalism if it is to be practically adequate in the contemporary world.

\section{Conclusions}

Societal institutionalist researchers act under an assumption - whether explicit or otherwise - that economic activity is always embedded in something (inter alia, a system of property rights, rules about corporate governance and financing, rules 
and less formal norms about the appropriate patterns of interaction between firms, social understandings about the rights and responsibilities of workers and so on). It is important to be clear that this is ultimately an ontological position. In other words, the assumption of embeddedness is not refuted by empirical findings that fail to show national effects in specific cases, or indeed, by 'deregulation' (Almond and Rubery, 2000). This means that a societal institutionalist can either test for the effects of specific institutions at specific geographical levels, or, alternatively, can attempt to understand the social and institutional foundations of actor choices, whether or not these lie primarily in national-level institutional arrangements. Because of this, as the frameworks governing economic activity have become progressively 'de-nationalised' as a result of broader changes in global political economy (Gilpin, 2011), societal institutionalists increasingly seek influences on patterns of the coordination of MNCs that may form at multiple transnational, sectoral and subnational levels (Morgan, 2007; Meyer and Nguyen, 2005; Djelic and Quack, 2010), as well as the more traditional national level.

But moving the analysis to different geographical levels does not resolve the more basic tension within societal institutionalism as to whether embeddedness itself is an assumption - which would mean that we could perform institutionalist analysis on the underpinnings of even relatively pure market forms of exchange (e.g. Biggart and Beamish, 2003) - or an alternative reading - which refers to embeddedness as meaning the social arrangements that have historically attempted to make capitalism, and market exchange, coherent with the stabilisation of society (Polanyi, 1944). Such arrangements are geographically variable, as the varieties of capitalism literature reflects. For example, Hall and Soskice's binary model posits that US and German styles of capitalism are roughly equally successful economically, but that the social compromises that shape them are different, with distinct distributional consequences. Equally, they are historically variable; institutionalised systems for the governance of capitalism are the crystallisation of contests of power between social actors, and liable to be subject to change when they no longer fulfil their economic or social roles, as judged by powerful contemporary actors (Streeck and Thelen, 2005).

Corporate globalisation, while clearly not the sole driving factor, has played a significant role in making the establishment and maintenance of coherent national business systems more difficult. MNCs, as is well known, 'shop' between regulatory and fiscal regimes with some alacrity, both when making location choices and in ongoing negotiations with host-country social and political actors (Kristensen and Rocha, 2012). There is also a known problem of 'cherry picking' (Geppert and Matten, 2006), where firms seek to 
drink from the well of positive outputs of national business systems - such as highly educated workforces - while seeking to abstain from contributing to the other components of these systems (e.g. welfare states, employment relations regimes) that have been central to the construction of these advantages. Additionally, MNCs are, collectively and often individually, powerful actors, with de facto and sometimes de jure negotiating power over the nature of many of the social compromises on which liberal and social democratic variants of capitalism are built, at least in so far as how these arrangements apply to them. In this context, it is important that a comparative institutionalist approach to transnational capitalism also interrogates societal embeddedness in its original Polanyian sense of the overall coherence of the means of organising the economy within society (Polanyi, 1944). Societal institutionalist research, if pursued in a geographically open and actor-sensitive manner, can make a key contribution to this endeavour by accessing the relations between societal spheres and their interlockages.

\section{References}

Almond, P., Gonzalez, M.C., Lavelle, J. and Murray, G. (2017), 'The local in the global: Regions, employment systems and multinationals', Industrial Relations Journal (forthcoming).

Almond, P., Gonzalez, M.C., Gunnigle, P., Lavelle, J, Luque, D., Monaghan, S. and Murray, G. (2014), 'Multinationals and regional economies: embedding the regime shoppers', Transfer, 20:2, 237-53.

Almond, P. and Rubery, J. (2000), 'Deregulation and societal systems', Advances in Organization Studies, 4, 277-94.

Andersson, U. and Forsgren, M. (1996), 'Subsidiary embeddedness and control in the multinational corporation', International Business Review, 5:5, 487-508.

Andersson, U. and Forsgren, M. (2002), 'In search of centre of excellence: Network embeddedness and subsidiary roles in multinational corporations', Management International Review, 40:4, 329-50.

Andersson, U., Forsgren, M. and Holm, U. (2002), 'The strategic impact of external networks: subsidiary performance and competence development in the multinational corporation', Strategic Management Journal, 23:11, 979-96.

Bélanger, J., Lévesque, C., Jalette, P. and Murray, G. (2013), 'Discretion in employment relations policy among foreign-controlled multinationals in Canada', Human Relations, 66:3, 307-32.

Belizón, M.J., Gunnigle, P. and Morley, M. (2013), 'Determinants of central control and subsidiary autonomy in HRM: the case of foreign-owned multinational companies in Spain', Human Resource Management Journal, 23:3, 262-78. 
Biggart, N. W. and Beamish, T. D. (2013), 'The economic sociology of conventions: habit, custom, practice, and routine in market order', Annual Review of Sociology, 29, 443-64.

Birkinshaw, J. (2013), 'How multinational subsidiary mandates are gained and lost', Journal of International Business Studies, 27:3, 467-95.

Brenner, N., Jessop, B., Jones, M. and MacLeod, G. (2003), 'Introduction: state space in question', in Brenner, N., Jessop, B., Jones, M. and MacLeod, G. (eds), State Space: A Reader (Oxford: Blackwell), pp. 1-26.

Cantwell, J. and Iammarino, S. (2000), 'Multinational corporations and the location of technological innovation in the UK regions', Regional Studies, 34:4, 317-32.

Cerny, P. (1997), 'Paradoxes of the competition state: the dynamics of political globalization' Government and Opposition, 32:2, 251-274.

Coe, N., and Yeung, H. (2015), Global Production Networks: Theorizing Economic Development in an Interconnected World (Oxford: Oxford University Press).

Coe, N., Hess, M. and Yeung, H. (2004), “'Globalizing” regional development: a global production networks perspective', Transactions of the Institute of British Geographers, 29:3, 468-84.

Crouch, C. (2005), Capitalist Diversity and Change (Oxford University Press: Oxford).

Djelic, M. L. and Quack, S. (2003), Globalization and Institutions. Redefining the Rules of the Economic Game (Aldershot: Elgar).

Djelic, M. L. and Quack, S. (eds) (2010), Transnational Communities: Shaping Global Economic Governance (Cambridge: Cambridge University Press).

Dörrenbächer, C. and Geppert, M. (eds) (2011), Politics and Power in the Multinational Corporation: The Role of Institutions, Interests and Identities (Cambridge: Cambridge University Press).

European Commission (2014), National/Regional Innovation Strategies for Smart Specialisation (RIS3) (Brussels: European Commission).

Geppert, M. and Matten, D. (2006), 'Institutional influences on manufacturing organization in multinational corporations: The 'cherrypicking' approach', Organization Studies, 27, 491-515.

Gertler, M.S. (2010), 'Rules of the game: the place of institutions in regional economic change', Regional Studies, 44:1, 1-15.

Gilpin, R. (2011), Global Political Economy: Understanding the International Economic Order (Princeton: Princeton University Press).

Gooderham, P., Nordhaug, O. and Ringdal, K. (2006), 'National embeddedness and calculative human resource management in US subsidiaries in Europe and Australia', Human Relations, 59:11, 1491-513.

Hall, P. and Soskice, D. (eds) (2001), Varieties of Capitalism (Oxford: Oxford University Press).

Herrigel G. and Zeitlin, J. (2010), 'Interfirm relations in global manufacturing: disintegrated production and its globalisation', in Morgan, G., Campbell, J., Crouch, C., Kristensen, P. H., Pedersen, O. and Whitley, R. (eds), The Oxford Handbook of Comparative Institutional Analysis (Oxford: Oxford University Press), pp. 527-61. 
Holst, H. (2013), 'Commodifying institutions: vertical disintegration and institutional change in German labour relations', Work Employment and Society, 28:1, 3-20.

Hudson, R. (2003), 'European integration and new forms of uneven development', European Urban and Regional Studies, 10:1, 49-67.

Jessop, B. (2004), Towards a Schumpetarian Workfare State? Preliminary Remarks on Post-Fordist Political Economy (Lancaster: University of Lancaster, originally 1993).

Jessop, B. (2013), 'Revisiting the regulation approach: Critical reflections on the contradictions, dilemmas, fixes and crisis dynamics of growth regimes', Capital and Class, $37: 1,5-24$.

Kristensen, P. H., and Rocha, R. S. (2012), 'New roles for the trade unions five lines of action for carving out a new governance regime', Politics and Society, 40:3, 453-79.

Kristensen, P. H. and Zeitlin, J. (2005), Local Players in Global Games (Oxford: Oxford University Press).

Lammers, C. and Hickson, D. (1979), Organisations Alike and Unlike (London: Routledge).

Lane, C. (1989), Management and Labour in Europe (Aldershot: Elgar).

Lundvall, B. A. (ed.) (2010), National Systems of Innovation: Toward a Theory of Innovation and Interactive Learning, Vol. 2 (London: Anthem Press).

Marsden, D. (2015), 'The future of the German Industrial Relations Model', Journal for Labour Market Research, 48:2, 169-87.

Maskell, P. and Malmberg, A. (1999), 'The competitiveness of firms and regions "Ubiquitification" and the importance of localized learning', European Urban and Regional Studies, 6:1, 9-25.

Maurice, M. (1979), 'For a study of the societal effect: universality and specificity in organisational research', in Lammers, C and Hickson, D. (eds), Organisations Alike and Unlike (London: Routledge).

Maurice, M. and Sorge, A. (eds) (2000), Embedding Organizations: Societal Analysis of Actors, Organizations and Socio-economic Context, Vol. 4 (Amsterdam: John Benjamins Publishing Company).

Maurice, M., Sellier, F., and Silvestre, J. J. (1986), The Social Foundations of Industrial Power: A Comparison of France and Germany (Cambridge, MA: MIT Press).

Meyer, K. E., and Nguyen, H. V. (2005), 'Foreign investment strategies and sub-national institutions in emerging markets: Evidence from Vietnam', Journal of Management Studies, 42:1, 63-93.

Michon, F. (1992), 'The institutional forms of work and employment: towards the construction of an international historical and comparative approach', in Castro, A., Méhaut, P., and Rubery, J. (eds), International Integration and Labour Market Organisation (London, Academic Press).

Morgan, G. (2001), 'Transnational communities and business systems', Global Networks, $1: 1,113-30$.

Morgan, G. (2007), 'National business systems research: Progress and prospects', Scandinavian Journal of Management, 23:2, 127-45.

Morgan, G. and Kristensen, P. H. (2006), 'The contested space of multinationals: varieties of institutionalism, varieties of capitalism', Human Relations, 59:11, 1467-90. 
Morgan, K. (1997), 'The Regional Animateur: taking stock of the Welsh Development Agency', Regional and Federal Studies, 7:2, 70-94.

Myloni, B., Harzing, A. and Mirza, H. (2004), 'Host country specific factors and the transfer of human resource management practices in multinational companies', International Journal of Manpower, 25:6, 518-34.

Parry, E., Dickmann, M. and Morley, M. (2008), 'North American MNCs and their HR policies in liberal and coordinated market economies', The International Journal of Human Resource Management, 19:11, 2024-40.

Peck, J. and Theodore, N. (2007), 'Variegated capitalism', Progress in human geography, 31:6, 731-772.

Polanyi, K. (1944), The Great Transformation: The Social and Political Origins of Our Time (Boston: Beacon Press).

Pedersen, O. (2010), 'Institutional competitiveness: How nations came to compete', in Morgan, G. Campbell, J., Crouch, C., Kristensen, P., Pedersen, O. and Whitley, R. (eds), The Oxford Handbook of Comparative Institutional Analysis (Oxford: Oxford University Press).

Rubery, J. (1992), 'Production systems, international integration and the single European market', in Castro, A., Méhaut, P., and Rubery, J. (eds), International Integration and Labour Market Organisation (London: Academic Press).

Rubery, J. (1994), 'The British production regime: a societal-specific system?', Economy and Society, 23:3, 335-54.

Saka-Helmout, A. and Geppert, M. (2011), 'Different forms of agency and institutional influences within multinational enterprises', Management International Review, 51:5, 567-92.

Sorge, A. (1991), 'Strategic fit and the societal effect: interpreting cross-national comparisons of technology, organization and human resources', Organization Studies, 12:2, 161-90.

Streeck, W. (1991), 'More uncertainties: German unions facing 1992', Industrial Relations, 30:3, 317-49.

Streeck, W. and Thelen, K.A. (2005), Beyond Continuity: Institutional Change in Advanced Political Economies (Oxford: Oxford University Press).

Whitley, R. (ed.) (1992), European Business Systems: Firms and Markets in their National Contexts (London: Sage).

Whitley, R. (1999), Divergent Capitalisms: The Social Structuring and Change of Business Systems (Oxford: Oxford University Press).

Wilkinson, F. (1983), 'Productive systems', Cambridge Journal of Economics, 7:3/4, 413-29. 